\title{
German cabinet promises gene law but problems remain
}

\section{Munich}

Giving birth to a new 'basic law' for regulating genetic engineering is giving the West German government labour pains. A Health Ministry report on the outline of the new law was received by the cabinet with a great fanfare in Bonn last month, but it is clear that important issues remain to be decided if the law is to be enacted before the end of next year.

The government hopes that a single, general law will close legal loopholes in the present patchwork of regulations. At the same time, the law will not to too specific. Instead, it will ensure that the regulations are regularly reviewed and updated to keep up with the technology.

The new law will probably not change regulatory procedures for universities that are carrying out basic research in

\section{Human gene therapy now on the way}

\section{Washington}

THE first experiment involving the introduction of foreign genes into humans got back on track through the institutional review process last week when it was approved by a subcommittee of the Recombinant DNA Advisory Committee (RAC) of the US National Institutes of Health (NIH).

The project, directed by NIH researchers Stephen A. Rosenberg and W. French Anderson, became derailed last month when NIH director James Wyngaarden required that the subcommittee reevaluate the project because they had not been given adequate information initially. This despite the fact that the full RAC had already approved the project (see Nature 335,577 and $754 ; 1988$ ).

The protocol calls for treating ten cancer patients by giving them tumour infiltrating lymphocytes (TIL) marked with genes for antibiotic resistance. The genes will have no therapeutic value to the patients, but will allow the cancer-killing TIL cells to be tracked in the patients' bodies.

The NIH institutional biosafety committee cleared the experiment early last month, but cautioned that its approval should not be construed as setting a precedent for allowing human gene therapy.

The protocol must now be approved by the National Heart Lung and Blood Institute's institutional review board, and be reapproved by the RAC. If it clears both these hurdles, the protocol will then be reviewed by the US Food and Drug Administration and NIH Director James Wyngaarden.

Carol Ezzell biotechnology.

Applications to conduct projects will be submitted to a central body such as the existing Central Commission for Biological Safety (ZKBS), which operates under the auspices of the Federal Health Office in Berlin. ZKBS can at present only request voluntary compliance with its decisions, whereas the new law could make violating a ZKBS order a criminal offence.

For industry, the situation is more complicated, especially in the case of intentional release of genetically modified organisms into the environment. The new law may closely resemble the pattern established in pollution control laws.

The extent to which the new law will mesh with or take precedence over existing laws is still undecided. The Health Ministry report urges that individual ministries give up much of their authority in areas they regulate to make the new law as broadly applicable as possible, but some, especially research and technology, agriculture and environment, may well resist.

The question of whether to declare a five-year moratorium on any release of a genetically modified organism is still open, to the exasperation of researchers. Such a moratorium was recommended by a parliamentary commission in January 1987. Nearly two years have gone by and a five-year moratorium is still a possibility.

The federal government gives itself precedence over the Länder in enforcing the new law, a move which will require the approval of the Länder and might provoke a political battle.

Liability law will certainly change. At present, West German law requires a clear chain of causality to be demonstrated in establishing liability. But in the case of a lawsuit against a university or industrial research institution for damages caused by genetic engineering, the government will make exceptions.

Areas such as genome analysis, gene therapies and the protection of human embryos in research were explicitly excluded from the new law, since the Justice Ministry is already hard at work on proposed laws covering those subjects. The results are expected by midsummer.

Basic researchers and West German industry are anxious for the law to be passed. Industry has postponed investments in the area of genetic engineering in anticipation. The government has promised to pass the law before the next parliamentary elections in late 1990 , but it must resolve the remaining issues by the midsummer recess in 1989 to allow for parliamentary debate. Steven Dickman

\section{Atlantis back safely}

THE secret defence mission of the space shuttle Atlantis ended successfully on Wednesday afternoon, 7 December, at Edwards Air Force Base in California, four and a half days after it lifted off from the Kennedy Space Center in Florida. Although mission details are classified, the reported goal was to deploy a high-resolution radar imager capable of mapping the Earth's surface in any weather condition. Atlantis's launch trajectory indicated that the satellite will orbit over the Soviet Union.

The only reported problem Atlantis encountered was the unusually large number of heat-shield tiles that were damaged during the mission. Between 125 and 175 tiles were either partially or completely destroyed. The National Aeronautics and Space Administration (NASA) has established a board of inquiry to determine the cause of the damage.

The next shuttle to fly will be Discovery, scheduled to place another Tracking and Data Relay Satellite into orbit next February. Atlantis's next flight, set for April, will be the long-awaited launch of the Magellan radar mapper mission to Venus.

\section{US award to France}

ON the occasion of its centenary celebrations, the US Geological Society awarded its gold medal to Claude Allègre, professor at the University of Paris VII and long-time director of the Institut de Physique du Globe and the laboratory of geochemistry and cosmochemistry that he founded in 1965 . It is the first time the society has awarded this distinction to a foreign scientist. Allègre has pioneered studies of the evolution of the Earth based on the isotopic composition of rock samples and has been instrumental in initiating several major international projects in geochemistry and global dynamics. In 1986 he received the Crafoord Prize from the Swedish Royal Academy.

P.C.

\section{SERC falls behind}

INCREASING inflation is causing concern within the Science and Engineering Council, and chairman of the Science Board, Professor Brian Fender, admitted that figures in the council's annual report, published last week, show that funds for research grants are not increasing as rapidly as he would like.

He also said the council was concerned that the number of postgraduate researchers might drop, and to prevent this the council was considering raising the level of grants. In addition, Fender said that the University Grants Committee reviews of physics and chemistry in universities which designated minimum sizes for departments were too inflexible; it will put its comments on the reviews to the full council this week. 